\title{
Regional $\Delta^{14} \mathrm{C}$ patterns and fossil fuel derived $\mathrm{CO}_{2}$ distribution in the Beijing area using annual plants
}

\author{
XI XianTing ${ }^{1,2}$, DING XingFang ${ }^{1}$, FU DongPo ${ }^{1}$, ZHOU LiPing $^{2} \&$ LIU KeXin ${ }^{1 *}$ \\ ${ }^{1}$ Institute of Heavy Ion Physics \& State Key Laboratory of Nuclear Physics and Technology, Peking University, Beijing 100871, China; \\ ${ }^{2}$ College of Urban and Environmental Science \& Laboratory for Earth Surface Process, Peking University, Beijing 100871, China
}

Received November 4, 2010; accepted January 31, 2011

\begin{abstract}
The level of atmospheric $\Delta{ }^{14} \mathrm{C}$ and the fossil fuel derived $\mathrm{CO}_{2}$ concentration in the Beijing area from May to September, 2009, were systematically analyzed based on radiocarbon $\left({ }^{14} \mathrm{C}\right)$ measurements of annual plants by accelerator mass spectrometry (AMS). The results show that the maximum $\Delta \Delta^{14} \mathrm{C}$ in Beijing was $29.6 \% \%^{2} .2 \%$, and the minimum was $-28.2 \% \pm \pm 2.5 \%$, with a trend of decreasing $\Delta^{14} \mathrm{C}$ from the outer suburbs to inner suburbs to the urban center. This trend correlates well with increases in fossil fuel derived $\mathrm{CO}_{2}$ caused by human activities such as population density, industrial emissions and traffic, with lower values of atmospheric $\Delta^{14} \mathrm{C}$ associated with more intensive human activities. The fossil fuel derived $\mathrm{CO}_{2}$ concentrations from May to September, 2009 , ranged from $3.9 \pm 1.0 \mathrm{ppm}$ to $25.4 \pm 1.0 \mathrm{ppm}$. It was calculated that each additional $1 \mathrm{ppm}$ of $\mathrm{CO}_{2}$ from fossil fuels depleted the atmospheric $\Delta{ }^{14} \mathrm{C}$ by approximately $2.70 \%$. This study suggests that ${ }^{14} \mathrm{C}$ measurements of annual plants by AMS provide an effective method to rapidly trace fossil fuel derived $\mathrm{CO}_{2}$.
\end{abstract}

accelerator mass spectrometry (AMS), Beijing area, annual plant, $\Delta^{14} \mathrm{C}$, fossil fuel derived $\mathrm{CO}_{2}$

Citation: $\quad$ Xi X T, Ding X F, Fu D P, et al. Regional $\Delta^{14} \mathrm{C}$ patterns and fossil fuel derived $\mathrm{CO}_{2}$ distribution in the Beijing area using annual plants. Chinese Sci Bull, 2011, 56: 1721-1726, doi: 10.1007/s11434-011-4453-8

Greenhouse gases, released by human activities since the industrial revolution, have increasingly contributed to global warming. Carbon dioxide $\left(\mathrm{CO}_{2}\right)$ is the most important anthropogenic greenhouse gas. During the period 1970-2004 global $\mathrm{CO}_{2}$ emissions increased by approximately $80 \%$, mainly because of the use of fossil fuels [1].

In 1957, the first measurement of atmospheric $\mathrm{CO}_{2}$ concentration was undertaken by Mauna Loa Observatory, Hawaii, US [2] Measurements of atmospheric $\mathrm{CO}_{2}$ then spread around the world because of the actions of the World Meteorological Organization (WMO) and the US National Oceanic and Atmospheric Administration (NOAA) in establishing a global air sampling network. At the same time, many countries independently initiated similar research $[3,4]$.

In China, atmospheric $\mathrm{CO}_{2}$ research was initiated rela-

*Corresponding author (email: kxliu@pku.edu.cn) tively late. In 1989, China's first global atmospheric background monitoring station was established at Waliguan in Qinghai Province. Following that, further greenhouse gas monitoring stations were established at Lin'an in Zhejiang Province, Longfengshan in Heilongjiang Province, Minqin in Gansu Province, Wudaoliang in Qinghai Province, and in Beijing. These monitoring stations tend to focus on the temporal variation in $\mathrm{CO}_{2}$ concentrations [5-11], and are rarely involved in determining regional distribution and source-sink analysis [12]. Research by Liu and Wang [10,11] on atmospheric $\mathrm{CO}_{2}$ concentrations in Beijing, 1993-2002, showed that the variation in $\mathrm{CO}_{2}$ concentration is caused by the combined effects of biological sinks (plants) and fossil fuel sources. It showed an overall increasing trend that became more rapid during the last 5 years of research, but the extent to which this is caused by fossil fuel emissions could not be determined.

Atmospheric ${ }^{14} \mathrm{CO}_{2}$ is considered to be one of the most 
sensitive tracers for monitoring fossil fuel derived $\mathrm{CO}_{2}$ [13]. ${ }^{14} \mathrm{C}$ is produced in the atmosphere by reactions between neutrons and atmospheric nitrogen induced by cosmic rays. This ${ }^{14} \mathrm{C}$ then enters the global carbon cycle after combining with oxygen in the atmosphere to produce ${ }^{14} \mathrm{CO}_{2}$. The ${ }^{14} \mathrm{CO}_{2}$ level in the atmosphere depends on the production rate of atmospheric ${ }^{14} \mathrm{C}$ [14], and also on carbon cycling processes including rates of ocean mixing and air-sea gas exchange [15], carbon cycling within terrestrial ecosystems [16], re-entrainment of older stratospheric air in the troposphere [17], and human activities. The amount of atmospheric ${ }^{14} \mathrm{CO}_{2}$ is disturbed by human activities via the ongoing emissions of fossil fuel $\mathrm{CO}_{2}[18]$ and nuclear weapon tests that occurred in the late 1950s and early 1960s [19]. After the nuclear tests, the level of ${ }^{14} \mathrm{C}$ in plants surged up to twice the normal level $[20,21]$.

Flask based measurements are the traditional method for measuring ${ }^{14} \mathrm{C}$ for research into fossil fuel derived $\mathrm{CO}_{2}$ in the atmosphere. Using flask measurements of ${ }^{14} \mathrm{CO}_{2}$, $\mathrm{CO}$ and $\mathrm{SF}_{6}$, Turnbull found that ${ }^{14} \mathrm{CO}_{2}$ was the most appropriate of the three tracers, and found that $1 \mathrm{ppm}$ of $\mathrm{CO}_{2}$ added from fossil fuels caused a depletion of $\Delta{ }^{14} \mathrm{C}$ by approximately $2.8 \%$ [13]. Another common sampling method is to use $\mathrm{NaOH}$ to absorb atmospheric $\mathrm{CO}_{2}$, but this method is more complicated and it can be difficult to collect $\mathrm{CO}_{2}$ samples from a wide area [22] at the same time. However, using this method Levin identified that fossil fuel derived $\mathrm{CO}_{2}$ in Europe has a spatial distribution characteristic [23]. The main disadvantage of these two sampling methods are that they can only be used for collecting samples over small time scales, for example, from hours to days. For long-term observations over a period of weeks to months, continuous sampling at the same location is necessary. Similarly, for sampling over a broad area, samples need to be collected at different sampling sites at approximately the same time. The two methods discussed above are inefficient and costly for this type of sampling.

For a simple and effective method to obtain trace level time-integrated measurements of fossil fuel derived $\mathrm{CO}_{2}$ in the atmosphere, Hsueh proposed the measurement of $\Delta^{14} \mathrm{C}$ in annual plants such as corn leaves to obtain the average level of fossil fuel derived $\mathrm{CO}_{2}$ during the whole growth period [24]. Compared to the flask or $\mathrm{NaOH}$ methods, Hsueh's method can be used to rapidly map large-scale environmental gradients in both rural and urban settings in an cost-effective manner, and its time-integration feature makes it possible to analyze the average seasonal and annual level of $\Delta{ }^{14} \mathrm{C}$. Atmospheric ${ }^{14} \mathrm{CO}_{2}$ is incorporated into plants by photosynthesis, and returns to the atmosphere by respiration, decay and decomposition, thus a dynamic balance of ${ }^{14} \mathrm{CO}_{2}$ in the atmosphere is achieved. Studies show that carbon in soil and groundwater, absorbed into the plant by the root system, comprises less than $0.3 \%$ of plant $\mathrm{C}$ [25]. Hsueh et al. [24] showed that annual plant measure- ments gave similar results to flask measurements at the same location. Wang and Pataki [26] used plant $\Delta^{14} \mathrm{C}$ measurements to study regional $\Delta^{14} \mathrm{C}$ patterns in the Los Angeles area in 2004-2005. Riley also has successfully applied this method to a study of the atmospheric transport model [27].

This study is the first time the annual plant method has been used to trace fossil fuel derived $\mathrm{CO}_{2}$ in China. Corn leaves were sampled at 23 locations across all districts and counties in Beijing in the summer of 2009. $\Delta^{14} \mathrm{C}$ was measured by accelerator mass spectrometry (AMS). In this paper, the regional $\Delta{ }^{14} \mathrm{C}$ patterns and the distribution of fossil fuel derived $\mathrm{CO}_{2}$ during May to September are presented.

\section{Sampling and methods}

\subsection{Study region}

Beijing is located in northwest of the North China Plain at $115^{\circ} 20^{\prime}-117^{\circ} 32^{\prime} \mathrm{E}$ and $39^{\circ} 23^{\prime}-41^{\circ} 05^{\prime} \mathrm{N}$. Beijing's terrain is elevated to the northwest and low-lying in the southeast. The Taihang Mt. lies to the west of Beijing and to the north is the Yanshan Mt. Beijing has a temperate continental monsoon climate, with four distinct seasons. In autumn and winter the dominant wind direction is northwesterly, and in summer the wind is predominantly southerly. Beijing is a very large city with a permanent population of 17.55 million and the land area is $16400 \mathrm{~km}^{2}$, of which $61.4 \%$ is mountain.

\subsection{Sampling}

Corn leaves were collected from all districts in Beijing in late September 2009. The location of the sampling points is shown in Figure 1. In each district, two sampling points were selected. To minimize the impact of local pollution, all sampling sites were more than $1 \mathrm{~km}$ from any highway, more than $100 \mathrm{~m}$ from any paved road, and $20 \mathrm{~m}$ from houses that use natural gas or fossil fuels for heating. For data reliability, three samples were collected at each sampling site, more than $1 \mathrm{~m}$ apart. The top leaves were sampled to reduce the impact of any ${ }^{14} \mathrm{C}$ in the soil.

\subsection{Sample preparation}

The samples were washed with an acid-base-acid pretreatment described by Santos [28] to remove any surface contaminants. After washing to neutral $\mathrm{pH}$ with de-ionized water, the samples were put into a vacuum oven with a drying temperature of $50^{\circ} \mathrm{C}$ for $24 \mathrm{~h}$. The samples were prepared at the College of Urban and Environmental Science \& Laboratory for Earth Surface Process, Peking University. The zinc reduction method was adopted for sample preparation [29]. It is simple method with a short preparation period, but is thought to have low precision and a high background compared to the hydrogen reduction 
method. It is suitable for the preparation of modern ${ }^{14} \mathrm{C}$ samples. During this preparation method, the carbon in the sample is oxidized to $\mathrm{CO}_{2}$ by copper oxide, then after purification, the $\mathrm{CO}_{2}$ is reduced to graphite with a zinc reducing agent under catalysis with iron powder on a vacuum line.

The graphite samples were measured at the Institute of Heavy Ion Physics \& State Key Laboratory of Nuclear Physics and Technology, Peking University [30]. The equipment was manufactured by NEC Corporation, with a precision below $\pm 3 \%$ and background ${ }^{14} \mathrm{C} /{ }^{12} \mathrm{C}$ value below $4 \times 10^{-16}$, which was consistent with the precision requirements of our $\Delta^{14} \mathrm{C}$ measurements. To ensure measurement accuracy, one international oxalic acid standard I (NBS OXI) and one international oxalic acid standard II (NBS OXII) were added after every seven samples, and two blank samples were also added in each wheel, 28 samples in one wheel. Using the measured OXII data, the standard deviation of each sample was determined to be $\pm 3.03 \%$.

The three samples collected at each site were prepared and measured separately. The mean value of the three samples was used for comparison and analysis.

\section{Results and discussion}

Based on the equation of Stuiver and Polach [31]:

$$
\Delta^{14} \mathrm{C}(\% \circ)=\left(\frac{A_{\mathrm{SN}}}{A_{\mathrm{abs}}}-1\right) \times 1000,
$$

where $A_{\mathrm{SN}}$ is the ${ }^{14} \mathrm{C}$ sample activity corrected by isotopic fractionation; and $A_{\mathrm{abs}}$ is the absolute international standard activity, processed by isotope fractionation correction and decay correction between 1950 and the year of measurement, 2009. Thus, the annual plant $\Delta^{14} \mathrm{C}$ distribution in Beijing is obtained, and has been tabulated in Table 1. Each $\Delta{ }^{14} \mathrm{C}$ value is the mean of three measurements from the same site, and should be a good indicator of the local atmospheric $\Delta^{14} \mathrm{C}$ level. Two types of error are listed, one is the AMS system error, which reflects the precision of the AMS measurement, and the other is the standard deviation of the three measurements, which reflects the local spatial fluctuation in $\Delta^{14} \mathrm{C}$. The maximum value was $29.6 \% \circ \pm 2.2 \%$, and the minimum value was $-28.2 \% \circ \pm 2.5 \%$. As can be seen from Table 1, the standard deviations for samples from Daxingzhuang, Shuangfengshan and Zhaoquanying are somewhat larger, and this may be because of point-source pollution caused by fossil fuel sourced $\mathrm{CO}_{2}$ emissions.

Background $\left(\mathrm{C}_{\mathrm{bg}}\right)$, terrestrial biosphere exchange $\left(\mathrm{C}_{\mathrm{bio}}\right)$, and fossil fuel emissions $\left(\mathrm{C}_{\mathrm{ff}}\right)$ are assumed to the three components of atmospheric $\mathrm{CO}_{2}$, with ocean exchange being neglected as Beijing is not a coastal city. Based on the

Table 1 Sampling location and $\Delta^{14} \mathrm{C}$ value in Beijing

\begin{tabular}{|c|c|c|c|c|c|}
\hline \multicolumn{2}{|c|}{ Sampling location } & \multirow{2}{*}{$\begin{array}{c}\text { Longitude } \\
116^{\circ} 17^{\prime} 13^{\prime \prime} \mathrm{E}\end{array}$} & \multirow{2}{*}{$\begin{array}{c}\text { Latitude } \\
40^{\circ} 41^{\prime} 09^{\prime \prime} \mathrm{N}\end{array}$} & \multirow{2}{*}{$\frac{\Delta^{14} \mathrm{C}(\% \circ) \text { (AMS system error) }}{29.6 \pm 2.7}$} & \multirow{2}{*}{$\frac{\Delta^{14} \mathrm{C}(\% o) \text { (standard deviation) }}{29.6 \pm 2.2}$} \\
\hline & Qianjiadian & & & & \\
\hline 1 वाтупा & Dayushu & $115^{\circ} 56^{\prime} 46^{\prime \prime} \mathrm{E}$ & $40^{\circ} 25^{\prime} 20^{\prime \prime} \mathrm{N}$ & $12.5 \pm 2.7$ & $12.5 \pm 2.0$ \\
\hline Huairou & Huaibei & $116^{\circ} 41^{\prime} 23^{\prime \prime} \mathrm{E}$ & $40^{\circ} 23^{\prime} 28^{\prime \prime} \mathrm{N}$ & $12.5 \pm 2.8$ & $12.5 \pm 3.6$ \\
\hline \multirow{2}{*}{ Miyun } & Taishitun & $117^{\circ} 06^{\prime} 59^{\prime \prime} \mathrm{E}$ & $40^{\circ} 32^{\prime} 09^{\prime \prime} \mathrm{N}$ & $21.4 \pm 3.3$ & $21.4 \pm 2.0$ \\
\hline & Jugezhuang & $116^{\circ} 53^{\prime} 51^{\prime \prime} \mathrm{E}$ & $40^{\circ} 21^{\prime} 52^{\prime \prime} \mathrm{N}$ & $23.4 \pm 2.7$ & $23.4 \pm 4.4$ \\
\hline \multirow{2}{*}{ Pinggu } & Huangsongyu & $117^{\circ} 15^{\prime} 35^{\prime \prime} \mathrm{E}$ & $40^{\circ} 13^{\prime} 42^{\prime \prime} \mathrm{N}$ & $15.6 \pm 3.2$ & $15.6 \pm 0.2$ \\
\hline & Daxingzhuang & $117^{\circ} 02^{\prime} 35^{\prime \prime} \mathrm{E}$ & $40^{\circ} 09^{\prime} 13^{\prime \prime} \mathrm{N}$ & $11.6 \pm 3.2$ & $11.6 \pm 8.6$ \\
\hline \multirow{2}{*}{ Mentougou } & Zhaitang & $115^{\circ} 41^{\prime} 47^{\prime \prime} \mathrm{E}$ & $39^{\circ} 57^{\prime} 44^{\prime \prime} \mathrm{N}$ & $17.0 \pm 2.5$ & $17.0 \pm 2.4$ \\
\hline & Shuangfengshan & $116^{\circ} 01^{\prime} 23^{\prime \prime} \mathrm{E}$ & $40^{\circ} 00^{\prime} 14^{\prime \prime} \mathrm{N}$ & $-7.1 \pm 3.5$ & $-7.1 \pm 6.4$ \\
\hline \multirow{2}{*}{ Changping } & Nankou & $116^{\circ} 09^{\prime} 19^{\prime \prime} \mathrm{E}$ & $40^{\circ} 14^{\prime} 07^{\prime \prime} \mathrm{N}$ & $-2.9 \pm 2.4$ & $-2.9 \pm 2.7$ \\
\hline & Nanshao & $116^{\circ} 17^{\prime} 01^{\prime \prime} \mathrm{E}$ & $40^{\circ} 11^{\prime} 23^{\prime \prime} \mathrm{N}$ & $3.9 \pm 2.6$ & $3.9 \pm 1.6$ \\
\hline Shunyi & Zhaoquanying & $116^{\circ} 34^{\prime} 28^{\prime \prime} \mathrm{E}$ & $40^{\circ} 11^{\prime} 22^{\prime \prime} \mathrm{N}$ & $6.9 \pm 3.6$ & $6.9 \pm 6.7$ \\
\hline \multirow{2}{*}{ Fangshan } & Yanshan & $115^{\circ} 54^{\prime} 56^{\prime \prime} \mathrm{E}$ & $39^{\circ} 44^{\prime} 01^{\prime \prime} \mathrm{N}$ & $-19.9 \pm 2.5$ & $-19.9 \pm 4.0$ \\
\hline & Chengguan & $116^{\circ} 01^{\prime} 01^{\prime \prime} \mathrm{E}$ & $39^{\circ} 42^{\prime} 27^{\prime \prime} \mathrm{N}$ & $-6.2 \pm 2.7$ & $-6.2 \pm 1.7$ \\
\hline \multirow{2}{*}{ Daxing } & Lixian & $116^{\circ} 26^{\prime} 20^{\prime \prime} \mathrm{E}$ & $39^{\circ} 34^{\prime} 04^{\prime \prime} \mathrm{N}$ & $13.9 \pm 3.7$ & $13.9 \pm 2.4$ \\
\hline & Huangcun & $116^{\circ} 21^{\prime} 04^{\prime \prime} \mathrm{E}$ & $39^{\circ} 40^{\prime} 22^{\prime \prime} \mathrm{N}$ & $7.7 \pm 2.4$ & $7.7 \pm 1.4$ \\
\hline \multirow{2}{*}{ Tongzhou } & Yongledian & $116^{\circ} 47^{\prime} 33^{\prime \prime} \mathrm{E}$ & $39^{\circ} 42^{\prime} 58^{\prime \prime} \mathrm{N}$ & $11.1 \pm 2.5$ & $11.1 \pm 3.5$ \\
\hline & Zhangjiawan & $116^{\circ} 44^{\prime} 36^{\prime \prime} \mathrm{E}$ & $39^{\circ} 51^{\prime} 19^{\prime \prime} \mathrm{N}$ & $2.9 \pm 2.4$ & $2.9 \pm 2.7$ \\
\hline \multirow{3}{*}{ Urban } & Ring road No.3 & $116^{\circ} 19^{\prime} 45^{\prime \prime} \mathrm{E}$ & $39^{\circ} 57^{\prime} 57^{\prime \prime} \mathrm{N}$ & $-28.2 \pm 2.6$ & $-28.2 \pm 2.5$ \\
\hline & Chengfu road & $116^{\circ} 18^{\prime} 43^{\prime \prime} \mathrm{E}$ & $39^{\circ} 59^{\prime} 29^{\prime \prime} \mathrm{N}$ & $-23.6 \pm 2.9$ & $-23.6 \pm 3.5$ \\
\hline & Weixiuyuan & $116^{\circ} 18^{\prime} 03^{\prime \prime} \mathrm{E}$ & $39^{\circ} 59^{\prime} 43^{\prime \prime} \mathrm{N}$ & $-7.3 \pm 3.0$ & $-7.3 \pm 3.0$ \\
\hline
\end{tabular}


conservation equation, the atmospheric $\mathrm{CO}_{2}$ concentration can be expressed as $\mathrm{C}_{\mathrm{m}}=\mathrm{C}_{\mathrm{bg}}+\mathrm{C}_{\text {bio }}+\mathrm{C}_{\mathrm{ff}}$. Similarly, atmospheric $\Delta^{14} \mathrm{C}\left(\Delta^{14} \mathrm{C}_{\mathrm{m}}\right)$ includes three similar components, which can be expressed as $\Delta{ }^{14} \mathrm{C}_{\mathrm{bg}}, \Delta \Delta^{14} \mathrm{C}_{\mathrm{bio}}$ and $\Delta^{14} \mathrm{C}_{\mathrm{ff}}$. Based on the definition of $\Delta^{14} \mathrm{C}$ and conservation principles, we can derive the following equation:

$$
\begin{aligned}
& \mathrm{C}_{\mathrm{m}}\left(\Delta^{14} \mathrm{C}_{\mathrm{m}}+1000\right)=\mathrm{C}_{\mathrm{bg}}\left(\Delta^{14} \mathrm{C}_{\mathrm{bg}}+1000\right) \\
& +\mathrm{C}_{\mathrm{bio}}\left(\Delta^{14} \mathrm{C}_{\mathrm{bio}}+1000\right)+\mathrm{C}_{\mathrm{ff}}\left(\Delta^{14} \mathrm{C}_{\mathrm{ff}}+1000\right),
\end{aligned}
$$

where the measured annual plant $\Delta^{14} \mathrm{C}\left(\Delta^{14} \mathrm{C}_{\mathrm{m}}\right)$ reflects the local atmospheric $\Delta \Delta^{14} \mathrm{C}$ level, $\Delta{ }^{14} \mathrm{C}_{\mathrm{ff}}=-1000 \%$ o $\left({ }^{14} \mathrm{C}\right.$ half-life is 5730 years). $\Delta^{14} \mathrm{C}_{\text {bio }}$ is mainly dependent on the mean terrestrial carbon residence time. A mean residence time of $10 \pm 10$ years is adopted by Turnbull and used to obtain a $\Delta \Delta^{14} C_{\text {bio }}$ of $166 \%$ $\pm 100 \%$ [13]. Studies by Levin and Kromer show the variation in $\mathrm{C}_{\text {bio }}$ in the winter is approximately $2 \pm 1$ ppm, and in summer is $5 \pm 2.5 \mathrm{ppm}$ [32]. The effect of this variation is $0.2-0.5 \mathrm{ppm}$ [13], which has little effect on the estimation of the relative concentration variation of fossil fuel derived $\mathrm{CO}_{2}$. Thus, although there is some biospheric isotopic disequilibrium, we can assume $\Delta^{14} \mathrm{C}_{\text {bio }}$ is almost the same as $\Delta{ }^{14} \mathrm{C}_{\mathrm{bg}}$, so $\Delta^{14} \mathrm{C}_{\mathrm{bio}} \approx \Delta^{14} \mathrm{C}_{\mathrm{bg}}$. From this calculation, the lower bound of $\mathrm{C}_{\mathrm{ff}}$ can be obtained. Simplifying equation 1 , above, we can obtain the value of the fossil fuel derived $\mathrm{CO}_{2}$ concentration as

$$
\mathrm{C}_{\mathrm{ff}}=\mathrm{C}_{\mathrm{m}} \frac{\Delta^{14} \mathrm{C}_{\mathrm{bg}}-\Delta^{14} \mathrm{C}_{\mathrm{cm}}}{\Delta^{14} \mathrm{C}_{\mathrm{bg}}+1000} .
$$

A background $\Delta^{14} \mathrm{C}$ value of about $35 \% 0-45 \%$, was measured by Xu Xiaomei at the KCCAMS Laboratory, UC Irvine University, Pt. Barrow during May to September 2009.
The estimated background $\mathrm{CO}_{2}$ level from May to September 2009, $384.96 \mathrm{ppm}$, is obtained from NOAA. Our calculation results indicate that $1 \mathrm{ppm}$ of fossil fuel derived $\mathrm{CO}_{2}$ emissions will deplete $\Delta^{14} \mathrm{C}$ by approximately $2.70 \%$ $\pm 0.02 \%$, with the error caused by the variation in background $\Delta^{14} \mathrm{C}$ from $35 \%$ o to $45 \%$. Although there is a latitudinal gradient in background $\Delta^{14} \mathrm{C}$, from equation 2 , we see that variations of up to $10 \%$ in $\Delta^{14} \mathrm{C}_{\mathrm{bg}}$ result in an error below $1 \%$. In this calculation, we can conclude that the error in the calculated fossil fuel derived $\mathrm{CO}_{2}$ concentration is less than $1 \%$ because of the approximately $2 \%-3 \% o \Delta \Delta^{14} \mathrm{C}$ measurement error.

As shown in Figure 1, the results can be divided into three categories, identified as the high $\Delta^{14} \mathrm{C}$ areas, moderate $\Delta^{14} \mathrm{C}$ areas and low $\Delta^{14} \mathrm{C}$ areas. The results indicate a decreasing trend from the outer suburbs to suburbs to urban areas. The high $\Delta^{14} \mathrm{C}$ areas $\left(15 \% \circ<\Delta^{14} \mathrm{C}<30 \%\right.$, indicated by "•") are mainly located in the mountainous outer suburban areas, including Miyun, Yanqing, Huairou, north of Pinggu and west of Mentougou. The moderate $\Delta^{14} \mathrm{C}$ areas $\left(0<\Delta^{14} \mathrm{C}\right.$ $<15 \%$, indicated by " $\boldsymbol{\Delta}$ ") are the southern outer suburbs and some other suburbs, including Yanqing, Huairou, south of Pinggu, Changping, Shunyi, Tongzhou and Daxing. The low $\Delta^{14} \mathrm{C}$ areas $\left(\Delta^{14} \mathrm{C}<0\right.$, indicated by " $\square$ ") are mainly located in urban and western suburbs, including east of Mentougou, west of Changping and Fangshan.

Based on the calculation that an additional $1 \mathrm{ppm}$ of fossil fuel derived $\mathrm{CO}_{2}$ corresponds to a decrease in $\Delta^{14} \mathrm{C}$ of $2.70 \%$, the fossil fuel derived $\mathrm{CO}_{2}$ emissions in high $\Delta^{14} \mathrm{C}$ area, the moderate $\Delta^{14} \mathrm{C}$ area and the low $\Delta^{14} \mathrm{C}$ area are estimated at $3.8 \pm 1.0 \mathrm{ppm}$ to $9.0 \pm 1.0 \mathrm{ppm}, 9.7 \pm 1.0 \mathrm{ppm}$ to $13.7 \pm 1.0 \mathrm{ppm}$,

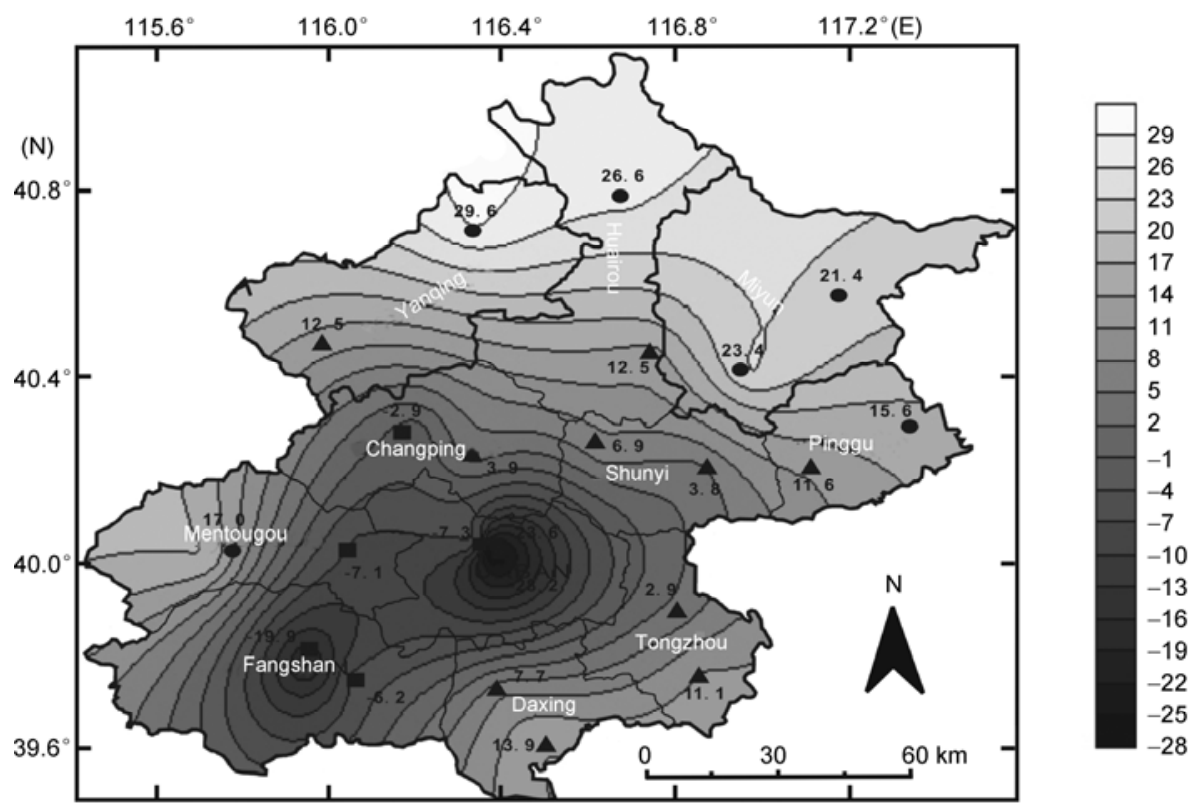

Figure 1 Sampling sites, $\Delta^{14} \mathrm{C}$ regional patterns and $\Delta^{14} \mathrm{C}$ contours. $\bullet$, High $\Delta^{14} \mathrm{C}$ areas, $15 \% \circ<\Delta^{14} \mathrm{C}<30 \%$; $\boldsymbol{\Delta}$, moderate $\Delta^{14} \mathrm{C}$ areas, $0<\Delta^{14} \mathrm{C}<15 \%$; $\boldsymbol{\bullet}$, low $\Delta^{14} \mathrm{C}$ areas, $\Delta^{14} \mathrm{C}<0$. 
and $15.9 \pm 1.0 \mathrm{ppm}$ to $25.2 \pm 1.0 \mathrm{ppm}$, respectively. The difference between two extremes $(3.8 \pm 1.0 \mathrm{ppm}$ and $25.2 \pm 1.0$ $\mathrm{ppm}$ ) is $21.4 \pm 1.0 \mathrm{ppm}$.

The $\Delta^{14} \mathrm{C}$ distribution in one region is a closed system related to local natural conditions, such as, terrain and meteorological conditions, and human activities such as population density, traffic and industrial emissions [26]. In Beijing, the east-west oriented Yanshan Mt. to the north and the northeast-southwest oriented Taihang Mt. to the west are connected and form an arc-shaped terrain, which plays an important role on lower air flow in the Beijing area. The dominant wind direction during the spring and summer (the corn growth season) is southerly, so at the intersection of the northwest mountainous area and the plains area, a wind convergence zone is formed roughly along topographic contour lines, and this is the so-called belt of convergence [33]. This belt of convergence substantially impacts fossil fuel derived $\mathrm{CO}_{2}$ transport to downwind areas such as Mengtougou and Changping which have lower $\Delta^{14} \mathrm{C}$ values than other suburban areas except Fangshan. On the upwind side, Fangshan and the urban center dominate the low $\Delta^{14} \mathrm{C}$ area. This trend can be clearly seen in the $\Delta^{14} \mathrm{C}$ contour in Figure 1.

Other important factors that impact the $\Delta^{14} \mathrm{C}$ distribution are human activities [18], such as population density, traffic, industrial emissions, and emissions from winter heating systems. Our study focuses on summer corn, whose growth period is from May to September, so the impact of winter heating systems can be neglected.

Most of the high $\Delta^{14} \mathrm{C}$ areas $\left(15 \% \circ<\Delta^{14} \mathrm{C}<30 \%\right.$ ) are located in the mountainous outer suburban area, which is typically far from industrial or densely populated areas. In these regions, the traffic volume is very low, with almost no anthropogenic pollution. In summer, the major fuel is crop residues rather than fossil fuels. Thus, the local $\Delta^{14} \mathrm{C}$ level is generally high, almost the same as the background value in the Beijing Area. The Shangdianzi atmospheric background monitoring station is located in the northeastern mountainous region, approximately $150 \mathrm{~km}$ from Beijing [12], and in our study, all the sampling sites with $\Delta^{14} \mathrm{C}>20 \%$ o were located in the northern mountainous area The maximum $\Delta^{14} \mathrm{C}$ value was measured in the mountainous area of Yanqing, where there are no industrial emissions, and fossil fuel emissions from daily activities and traffic are very low. The minimum value in the high $\Delta^{14} \mathrm{C}$ area was measured to the north of Pinggu, and is mainly attributed to relatively large traffic volumes in this area.

In contrast, the moderate $\Delta^{14} \mathrm{C}$ area $\left(0<\Delta^{14} \mathrm{C}<15 \%\right.$ o $)$ is much closer to the urban center. The $\Delta^{14} \mathrm{C}$ values decrease close to the urban center. In this area, the population density and traffic volume are less than in the urban areas, but much higher than in the high $\Delta^{14} \mathrm{C}$ area. There are few industrial emissions of $\mathrm{CO}_{2}$ in this area. The $\Delta^{14} \mathrm{C}$ level is mainly caused by the $\mathrm{CO}_{2}$ emissions from daily activities and automobile exhausts.

In all of the low $\Delta^{14} \mathrm{C}$ areas $\left(\Delta^{14} \mathrm{C}<0\right)$, which include the Beijing Municipal District, Yanshan Petrochemical zone in Fangshan, and the coal zone in Mentougou, there are anthropogenic pollutant sources. The urban sampling sites are beside trunk roads or in residential areas. The $\mathrm{CO}_{2}$ emissions from natural gas during daily activities, and automobile exhaust emissions mean that fossil fuel derived $\mathrm{CO}_{2}$ emissions in the urban areas are much higher than in the suburbs. As the number of private cars has increased, vehicle $\mathrm{CO}_{2}$ emissions have also increased significantly. The minimum $\Delta \Delta^{14} \mathrm{C}$ value in this area, $-28.2 \% \circ \pm 2.5 \%$ was measured by the North Third Ring Road, while another sampling site on a trunk road, Chengfu Road, had a measured $\Delta^{14} \mathrm{C}$ value of $-23.6 \% \circ \pm 3.5 \%$. However in a nearby residential area, Weixiu garden, the $\Delta^{14} \mathrm{C}$ was $-7.3 \% \circ \pm 3.0 \%$, which is $15 \%$ - $-20 \%$ o higher than that measured by a trunk road in the same area. This significant difference is caused by differences in the traffic volume. The two sites are very interesting, and the $\Delta^{14} \mathrm{C}$ at the Yanshan petrochemical zone, Fangshan was $-19.9 \%$ $\pm 4.0 \%$, while at Shuangfeng Shan in the Mentougou coal zone the $\Delta^{14} \mathrm{C}$ was $-7.1 \%$ w $3.5 \%$. Although the population density and traffic volumes in these areas are much lower than in the urban areas, the industrial emissions of fossil fuel derived $\mathrm{CO}_{2}$ decreased $\Delta^{14} \mathrm{C}$ significantly, especially in the Yanshan petrochemical area, where $\Delta^{14} \mathrm{C}$ is $-19.9 \% \circ \pm 4.0 \%$, $20 \%$ - $30 \%$ o lower than in other suburbs. Therefore, compared to emissions from daily activities, traffic and industrial emissions have a more significant impact on the $\Delta^{14} \mathrm{C}$ level.

From the $\Delta^{14} \mathrm{C}$ distribution and the analysis above, we can conclude that $\Delta^{14} \mathrm{C}$ measurements from annual plants provide a fast and effective approach for tracing fossil fuel derived $\mathrm{CO}_{2}$ concentrations.

\section{Conclusions}

(1) An increase of $1 \mathrm{ppm}$ of $\mathrm{CO}_{2}$ derived from fossil fuels depletes $\Delta^{14} \mathrm{C}$ by approximately $2.70 \%$. The fossil fuel derived $\mathrm{CO}_{2}$ concentration during May to September was estimated in Beijing, with a maximum of $25.2 \pm 1.0 \mathrm{ppm}$ and a minimum of $3.8 \pm 1.0 \mathrm{ppm}$.

(2) $\Delta^{14} \mathrm{C}$ regional patterns were plotted using measurements from annual plants. The results show a decreasing trend from the outer suburbs to inner suburbs to urban areas, which is well correlated with the increase in fossil fuel derived $\mathrm{CO}_{2}$ caused by human activities such as population density, industrial emissions and traffic. As the human activities intensify, the value of atmospheric $\Delta^{14} \mathrm{C}$ decreases, with traffic and industrial emissions contributing more than population density.

(3) $\Delta^{14} \mathrm{C}$ measurements from annual plants are sensitive and can reflect the $\Delta^{14} \mathrm{C}$ variations over a large spatial and 
temporal scale. This method provides a simple and effective method for tracing fossil fuel derived $\mathrm{CO}_{2}$ concentrations over periods of weeks to months. This approach can be used to complement the traditional flask measurement method.

1 IPCC. Climate change 2007: the physical science basis. Summary for policymakers. Contribution of working group I to the fourth assessment report. IPCC, 2007

2 Keeling C D. Atmospheric carbon dioxide variations at Mauna Loa observatory, Hawaii. Tellus, 1976, 28: 538-551

3 Conway T J, Tans P P, Waterman L S, et al. Evidence for interannual variability of the carbon cycle from the NOAA/CMDL global air sampling network. J Geophys Res, 1994, 99: 22831-22855

4 Levin I, Graul R, Trivett B A N. Long-term observations of atmospheric $\mathrm{CO}_{2}$ and carbon isotopes at continental sites in Germany. Tellus, 1995, 47: 23-34

5 Wen Y P, Tang J, Shao Z Q, et al. A study of atmospheric $\mathrm{CO}_{2}$ concentration variations and emission from the soil surface at MT. Waliguan (in Chinese). Q J Appl Meteorol, 1997, 8: 129-136

6 Wang M L, Li X S. Analysis on the concentration of $\mathrm{CH}_{4}, \mathrm{CO}_{2}$ and $\mathrm{CO}$ in atmosphere watch observatory. In: Li Q S, ed. Analysis on Atmospheric Trace Gas and Other Chemical Substance in China and West Pacific (in Chinese). Beijing: China Meteorological Press, 1986. $172-185$

7 Wang G C, Wen Y P, Kong Q X, et al. The concentration of $\mathrm{CO}_{2}$ and its variation in China. Chinese Sci Bull, 2002, 47: 780-783

8 Zhou L X, Thomas J C, James W C, et al. Long-term record of atmospheric $\mathrm{CO}_{2}$ and stable isotopic ratios at Waliguan Observatory: Background features and possible drivers, 1991-2002. Glob Biogeochem Cycles, 2005, 19, doi: 10.1029/2004GB002430

9 Wang C K, Wang Y S, Liu G R, et al. Characteristics of atmospheric $\mathrm{CO}_{2}$ variations and some affecting factors in urban area of Beijing (in Chinese). Environ Sci, 2003, 24: 13-17

10 Liu Q, Wang Y S, Wang M X, et al. Trends of greenhouse gases in Recent 10 Years in Beijing (in Chinese). Chin J Atoms Sci, 2005, 29: 267-271

11 Wang Y S, Wang C K, Guo X Q, et al. Trend, seasonal and diurnal variations of atmospheric $\mathrm{CO}_{2}$ in Beijing. Chinese Sci Bull, 2002, 47: 2050-2055

12 Liu L X, Zhou L X, Zhang X C, et al. The characteristics of atmospheric $\mathrm{CO}_{2}$ concentration variation at four national background stations in China. Sci China Ser D-Earth Sci, 2009, 52: 1857-1863

13 Turmbull J C, Miller J B, Lehman S J, et al. Comparison of ${ }^{14} \mathrm{CO}_{2}$, $\mathrm{CO}$, and $\mathrm{SF}_{6}$ as tracers for recently added fossil fuel $\mathrm{CO}_{2}$ in the atmosphere and implications for biological $\mathrm{CO}_{2}$ exchange. Geophys Res Lett, 2006, 33: L01817, doi:10.1029/2005GL024213

14 Lingenfelter R E. Production of carbon 14 by cosmic-ray neutrons. Rev Geophys, 1963, 1: 35-55
15 Broecker W S, Peng T H, Ostlund G, et al. The distribution of bomb radiocarbon in the ocean. J Geophys Res, 1985, 90: 6953-6970

16 Trumbore S. Age of soil organic matter and soil respiration: Radiocarbon constraints on belowground C dynamics. Ecol Appl, 2000, 10: 399-411

17 Hesshaimer V, Levin I. Revision of the stratospheric bomb ${ }^{14} \mathrm{CO}_{2}$ inventory. J Geophys Res, 2000, 105: 11641-11658

18 Suess H E. Radiocarbon concentration in modern wood. Science, 1955, 122: 415-417

19 Cain W F, Suess H E. Carbon 14 in tree rings. J Geophys Res, 1976, 81: 3688-3694

20 Levin I, Kromer B, Schoch-Fischer H, et al. Twenty-five years of tropospheric ${ }^{14} \mathrm{C}$ observations in Central Europe. Radiocarbon, 1985, 27: $1-19$

21 Nydal R, Lovseth K. Tracing bomb ${ }^{14} \mathrm{C}$ in the atmosphere 1962 1980. J Geophys Res, 1983, 88: 3621-3642

22 Levin I, Münnich K O, Weiss W. The effect of anthropogenic $\mathrm{CO}_{2}$ and ${ }^{14} \mathrm{C}$ sources on the distribution of ${ }^{14} \mathrm{CO}_{2}$ in the atmosphere. Radiocarbon, 1980, 22: 379-391

23 Levin I, Kromer B, Schmidt M, et al. A novel approach for independent budgeting of fossil fuel $\mathrm{CO}_{2}$ observations. Geophys Res Lett, 2003, 30: 2194, doi: 10. 1029/2003GL018477

24 Hsueh D Y, Krakauer N, Randerson J T, et al. Regional patterns of radiocarbon and fossil fuel-derived $\mathrm{CO}_{2}$ in surface air across North America. Geophys Res Lett, 2007, 34, doi: 10.1029/2006GL027032

25 Tauber $\mathrm{H}$. Possible depletion in ${ }^{14} \mathrm{C}$ in tree rings growing in calcareous soils. Radiocarbon, 1983, 25: 417-420

26 Wang W W, Pataki D E. Spatial patterns of plant isotope tracers in the Los Angeles urban region. Landsc Ecol, 2010, 25: 35-52

27 Riley W J, Hsueh D Y, Randerson J T, et al. Where do fossil fuel carbon dioxide emissions from California go? An analysis based on radiocarbon observations and an atmospheric transport model. J Geophys Res, 2008, 113, doi: 10.1029/2007JG000625

28 Santos G M, Southon J R, Druffel-Rodriguez K C, et al. Magnesium perchlorate as an alternative water trap in AMS graphite sample preparation at KCCAMS at the University of California, Irvine. Radiocarbon, 2004, 46: 165-173

29 Xu X M, Trumbore S E, Zheng S H, et al. Modifying a sealed tube zinc reduction method forpreparation of AMS graphite targets: Reducing background and attaining high precision. Nucl Instr Meth B, 2007, 259: 320-329

30 Liu K X, Ding X F, Fu D P, et al. A new compact AMS system at Peking University. Nucl Instr Meth B, 2007, 259: 23-26

31 Stuiver M, Polach H. Discussion: Reporting of ${ }^{14} \mathrm{C}$ data. Radiocarbon, 1977, 19: 355-363

32 Levin I, Kromer B. The tropospheric ${ }^{14} \mathrm{CO}_{2}$ level in midlatitudes of the Northern Hemisphere (1959-2003). Radiocarbon, 2004, 46: 1261 $-1272$

33 Liu S H, Liu Z X, Li J, et al. Numerical simulation for the coupling effect of local atmospheric circulations over the area of Beijing, Tianjin and Hebei Province. Sci China Ser D-Earth Sci, 2009, 52: 382-392

Open Access This article is distributed under the terms of the Creative Commons Attribution License which permits any use, distribution, and reproduction in any medium, provided the original author(s) and source are credited. 